\title{
KONTRIBUSI IKLIM KOMUNIKASI DAN MOTIVASI BERPRESTASI TERHADAP KEPUASAN KERJA GURU MTSN LANGSAT KADAP RAO PASAMAN
}

\author{
Faizah \\ Guru MTSN Lansat Kadap Rao Pasaman \\ Koresponden: Langsat Kadap Rao Pasaman \\ $+20$
}

\begin{abstract}
The Contributions climate communication and achievement motivation toward job satisfaction teachers of MTsN Langsat Kadap Rao Pasaman. This study is aimed at identifying and describing the direct influence of: (1) to determinase whether there is a achievement communation climate contribution toward work satisfaction of teachers MTsN Langsat Kadap Rao Pasaman. (2) to determinase whether there is a achievement achievement motivation contribution toward work satisfaction of teachers MTsN Langsat Kadap Rao Pasaman. (3) to determinase whether there is a achievement communication climate and achievement motivation contribution simultaneously toward work satisfaction of teachers MTsN Langsat Kadap Rao Pasaman. This study used quantitative methods with two-way analysis variance. The population were all junior high school teachers in Sipoholon District of North Tapanuli numbered 60 persons and sample 32 persons which were determined by proportional stratified sampling technique. The data was collected by using the instrument. Prior to testing the hypothesis, the normality of the data was tested by using correlation, linearity and regression equations test were used by anava and homogeneity was tested by Bartlett test. The results show that the variable of communication climate and achievement motivation can be used as a factor in determining the performance of MTsN Langsat Kadap Rao Pasaman.
\end{abstract}

Kata Kunci: Iklim komunikasi, motivasi berprestasi, kepuasan kerja guru.

\section{PENDAHULUAN}

Pendidikan merupakan salah satu aspek penting dalam rangka pembangunan suatu bangsa. Kemajuan bangsa ditentukan oleh pendidikan. Pemerintah telah berusaha untuk memperbaiki pendidikan ini melalui perbaikan sistem pendidikan. Untuk dapat menyelenggarakan dengan baik salah satu sub sistem yang berpengaruh adalah guru, di mana guru merupakan pelaksana utama pendidikan. Hasil dan mutu pendidikan tergantung pada kualitas dan kinerja yang diperlihatkan oleh guru. Kinerja yang baik akan muncul dari rasa puas akan pekerjaan dan lingkungan tempat bekerja. Guru merupakan salah satu sub sistem dari pendidikan yang langsung berhubungan dengan siswa. Untuk itu dibutuhkan guru 
yang mempunyai komitmen yang tinggi. Komitmen yang tinggi akan didapat jika guru-guru merasa puas akan pekerjaan dan lingkungannya.

Keberhasilan guru dalam mencapai prestasi dan produktivitas kerja ditentukan oleh banyak faktor. Salah satunya adalah faktor kepuasan kerja. Kepuasan kerja perlu mendapat perhatian yang serius oleh semua pihak karena sangat berpengaruh terhadap pencapaian tujuan dan kelancaran aktivitas pembelajaran. Sebagaimana yang disampaikan oleh Robbins (1996: 170) yang mengatakan bahwa " seseorang dengan tingkat kepuasan kerja yang tinggi menunjukkan sikap positif terhadap pekerjaan itu, seseorang yang tidak puas akan menunjukkan sikap negatif tehadap pekerjaan itu.

Kepuasan kerja menjadi salah satu faktor yang harus diperhatikan. Apabila guru merasakan kepuasan dalam bekerja, maka akan tercipta suasana yang penuh kebersamaan, memiliki tanggung jawab yang sama, iklim komunikasi yang baik dan juga motivasi kerja yang tinggi sehingga tujuan organisasi atau sekolah dapat tercapai secara maksimal. Sebaliknya apabila guru tidak merasa puas, maka akan tercipta suasana membosankan, dan semangat kerja yang rendah.

Pra survey yang dilakukan terhadap guruguru MTsN Langsat Kadap Rao Pasaman mengarah kepada beberapa indikasi yang menunjukkan masih rendahnya kepuasan kerja guru. Gejala ini terlihat pada rendahnya kegairahan dalam melaksanakan tugas, tingkat kerajinan yang rendah ditandai dengan banyaknya guru yang tidak melaksanakan persiapan mengajar, datang terlambat, memulai jam pelajaran tidak tepat waktu, mengakhiri jam pada awal waktu terutama pada jam terakhir, rendahnya inisiatif dan kreativitas guru dan lemahnya jalinan kerjasama antar teman sekantor. Keluhankeluhan yang diungkapkan oleh guru adanya kesenjangan yang mereka dapatkan dengan yang mereka harapkan, berkaitan dengan kesejahteraan guru, misalnya imbalan yang mereka terima tidak memenuhi harapan mereka, penghargaan atas prestasi yang mereka raih kurang mendapat perhatian. Gejala-gejala yang mencerminkan rendahnya kepuasan kerja guru ini akan berdampak negatif jika dibiarkan, akan dapat menurunkan produktifitas kerja yang pada akhirnya akan menurunkan mutu pendidikan.

Iklim komunikasi yang kurang kondusif di sekolah ini juga terlihat seperti sikap atasan terhadap bawahan dalam berkomunikasi, guru-guru jarang dimintai saran dalam mengambil keputusan. Dari hasil wawancara dengan Wakil Kepala Bidang Sarana dan Prasarana MTsN Langsat Kadap Rao Pasaman diperoleh informasi bahwa interaksi antara kepala Madrasah dengan guru yang secara informal tidak begitu aktif, sedangkan secara formal hanya terjadi pada saat pertemuan rutin sekali sebulan. Apabila pertemuan terjadi lebih dari sekali merupakan pertemuan yang sifatnya insidentil untuk membicarakan hal yang mendesak yang perlu segera diinformasikan. Pendapat dan masukan dari guru-guru disampaikan hanya melalui pertemuan tersebut karena kesempatan untuk menyampaikan di luar terbatas. Apabila guru menghadapi suatu hambatan maupun kurang 
jelas akan suatu hal, maka akan lebih sering berkomunikasi dengan sesama rekannya.

Iklim komunikasi yang efektif tentunya harus dikembangkan dengan baik seperti yang dikemukakan Danim bahwa iklim komunikasi yang kondusif antara pimpinan dengan bawahan atau sebaliknya dan antara sesama karyawan menjadi keniscayaan bagi penciptaan semangat kerja dalam kelompok. Faktor lain yang diduga ikut mempengaruhi kepuasan kerja guru adalah motivasi berprestasi. Guru yang mempunyai motivasi tinggi akan bekerja keras, berusaha semaksimal mungkin melaksanakan tugas dengan baik dan mengatasi rintangan yang ditemui dalam menjalankan tugas dan tanggung jawab sehingga pekerjaan dapat berhasil. Keberhasilan yang dicapai akan dapat menimbulkan rasa puas dalam diri guru

Gejala-gejala yang mencerminkan rendahnya kepuasan kerja guru seperti yang dikemukakan di atas berdampak negatif jika dibiarkan, karena rendahnya kepuasan kerja pada akhirnya akan dapat menurunkan produktivitas kerja. Jika hal ini tidak ditanggulangi secara tepat akan menjadi kendala dalam mencapai tujuan pendidikan yang telah ditetapkan.

Berdasarkan uraian di atas, masalah ini yang menjadi alasan bagi peneliti melakukan penelitian tentang kepuasan kerja guru di MTsN Langsat Kadap. Sehingga dengan penelitian ini diharapkan dapat menemukan solusi untuk mengatasi yang berhubungan dengan kepuasan kerja guru tersebut.

Menurut Davis (1998: 86) faktor-faktor yang mempengaruhi kepuasan kerja guru adalah: supervisi, rasa aman, gaji atau insentif, kebijakan organisasi, gaya kepemimpinan atasan, motivasi prestasi kerja, iklim organisasi, pengembangan diri, iklim komunikasi. Selanjutnya menurut Veithzal Rivai (2010: 860), faktor-faktor untuk mengukur kepuasan kerja karyawan adalah : a) isi pekerjaan, b) supervisi, c) organisasi dan manajemen, d) kesempatan untuk maju, e) gaji, f) rekan kerja, g) kondisi pekerjaan.

Iklim komunikasi berpengaruh terhadap kepuasan kerja guru. Iklim komunikasi yang kondusif perlu diciptakan disekolah. Komunikasi merupakan salah satu aspek yang sangat esensial bagi kelancaran tugas-tugas di sekolah, tanpa komunikasi yang baik tidak akan tercapai tujuan pendidikan sebagaimana yang diharapkan.

Iklim komunikasi merupakan faktor yang krusial dalam organisasi, terutama dalam usaha pencapaian tujuan organisasi secara efektif dan efisien. Menurut Goldhaber dalam Arni (2002:81) bahwa iklim komunikasi adalah sangat krusial dalam organisasi. Ini berarti bahwa iklim komunikasi yang kondusif perlu dalam suatu madrasah. Iklim komunikasi yang kondusif disamping menghalangi konflik diantara personil sekaligus mendorong personil sekolah untuk bekerja sungguh-sungguh sehingga akan berdampak pada hasil kerjanya.

Motivasi berprestasi diduga mempunyai kontribusi tersendiri terhadap kepuasan kerja guru. Guru dengan motivasi berprestasi tinggi akan bekerja keras, berusaha untuk mengatasi segala rintangan dalam menjalankan tugas dan tanggung jawabnya sampai mereka berhasil. Keberhasilan yang mereka capai 
akan menyebabkan mereka puas dalam pekerjaannya. Dengan demikian apabila guru mempunyai motivasi berprestasi yang tinggi diduga dapat meningkatkan kepuasan kerjanya

Bertitik tolak dari masalah yang telah dikemukakan di atas, maka masalah penelitian ini dapat dirumuskan sebagai berikut : 1) Apakah terdapat kontribusi iklim komunikasi terhadap kepuasan kerja guru MTsN Langsat kadap Rao Pasaman ?. 2) Apakah terdapat kontribusi motivasi berprestasi terhadap kepuasan kerja guru MTsN Langsat kadap Rao Pasaman? 3) Apakah terdapat kontribusi iklim komunikasi dan motivasi berprestasi terhadap kepuasan kerja guru MTsN Langsat kadap Rao Pasaman?

Berdasarkan apa yang telah dipaparkan di atas maka, dapat dijelaskan kerangka berpikir dalam penelitian ini, adalah sebagai berikut:

\section{Kontribusi Iklim Komunikasi terhadap Kepuasan Kerja Guru}

Iklim komunikasi adalah salah satu faktor yang mempengaruhi kepuasan kerja guru. Iklim komunikasi yang kondusif dapat meningkatkan kepuasan kerja guru. Supaya tercipta iklim komunikasi yang baik sehingga kepuasan kerja dalam organisasi dapat terlaksana ada beberapa hal yang dapat dilakukan pimpinan yaitu:

a. Menjelaskan tujuan organisasi kepada karyawan

b. Membantu karyawan agar lebih efektif dalam pekerjaannya.

c. Memfokuskan perhatian pada kemajuan karyawan, bukan pada tingkah laku yang menyimpang. d. Membimbing karyawan agar dapat bekerjasama dengan baik.

Dari paparan di atas bisa kita lihat jika kepala sekolah bersama guru dapat menciptakan iklim komunikasi yang kondusif diantaranya dengan cara menjelaskan tujuan organisasi, membimbing dan membantu guruguru agar lebih efektif dalam pekerjaannya, serta dengan mengikutsertakan guru-guru dalam mengambil keputusan keputusan maka akan berdampak kepada kepuasan kerja

Dengan iklim komunikasi yang kondusif pesan yang disampaikan oleh kepala sekolah dapat diterima dengan baik oleh guru dan guru tidak ragu-ragu dalam menghadapi pekerjaannya. Selain itu iklim komunikasi yang kondusif memberi kesempatan kepada guru untuk menyampaikan informasi mengenai kesulitan yang dialami dalam melaksanakan tugas. Hal ini akan berdampak kepada kepuasan guru dalam bekerja. Hal ini dapat dikatakan bahwa iklim komunikasi mempunyai korelasi yang tinggi dengan kepuasan. Berdasarkan alasan di atas iklim komunikasi di sekolah diduga memberi kontribusi terhadap kepuasan kerja guru.

\section{Kontribusi Motivasi Berprestasi terhadap kepuasan kerja guru}

Sebagaimana yang telah diuraikan di atas motivasi berpretasi merupakan salah satu faktor yang mempengaruhi kepuasan kerja. Motivasi berprestasi seorang guru merupakan dorongan pada diri guru tersebut sehingga dia mau bekerja keras untuk melakukan tugasnya sebaik mungkin. Guru yang mempunyai motivasi berprestasi yang tinggi akan senantiasa 
bekerja keras untuk mengatasi segala jenis permasalahan yang dihadapi dengan harapan mencapai prestasi. Prestasi yang dicapai akan menimbulkan rasa bahagia sehingga kepuasan kerja akan meningkat

Seorang guru harus mempunyai motivasi berprestasi yang tinggi dalam melaksanakan pekerjaan penuh perhitungan akan resiko yang mungkin timbul sehingga tindakannya rasional dan tidak mudah menyerah. Oleh karena itu guru yang mempunyai motivasi berprestasi yang tinggi cendrung untuk berhasil dan berprestasi. Dengan prestasi yang dicapai tersebut kepuasan kerja mereka akan meningkat.

Dari analisis pemikiran itu diduga motivasi berprestasi berkontribusi terhadap kepuasan kerja guru.

\section{Kontribusi Iklim Komunikasi dan Motivasi Berprestasi terhadap kepuasan kerja guru}

Kepuasan kerja guru adalah suatu perasaan yang ada dalam diri guru seperti perasaan senang, lega, puas terhadap suasana dan lingkungan pekerjaan. Kepuasan kerja dipengaruhi oleh berbagai faktor diantaranya iklim komunikasi dan motivasi berprestasi.

Dengan iklim komunikasi yang kondusif guru akan mendapat informasi yang cukup tentang pekerjaannya sehingga jelas apa yang harus dilaksanakan dan apa yang akan di dapat dari pekerjaan tersebut. Disamping itu dengan kondusifnya iklim komunikasi, pimpinan sekolah akan lebih cepat mengetahui kebutuhan dan hambatan yang dihadapi guru dan dapat diberikan bantuan dengan cepat atau penghargaan kepada guru-guru yang berprestasi sesuai dengan harapan guru, yang akhirnya akan meningkatkan kepuasan kerja guru.

Disamping iklim komunikasi, motivasi berprestasi juga berkontribusi terhadap kepuasan kerja guru. Motivasi berprestasi yang tinggi akan membuat guru senantiasa berusaha untuk melakukan semua tugas dengan sebaik-baiknya. Jika ada hambatan berusaha semaksimalnya untuk mengatasinya, sehingga guru dapat mencapai prestasi yang diharapkannya. Prestasi yang dihaparkannya dapat meningkatkan kepuasan kerja guru

Dari uraian di atas iklim komunikasi dan motivasi berprestasbaik secara terpisah maupun secara bersama-sama diduga memberikan kontribusi terhadap kepuasan kerja guru. Untuk lebih jelasnya dapat kita gambarkan konsep dari penelitian ini sebagai berikut:

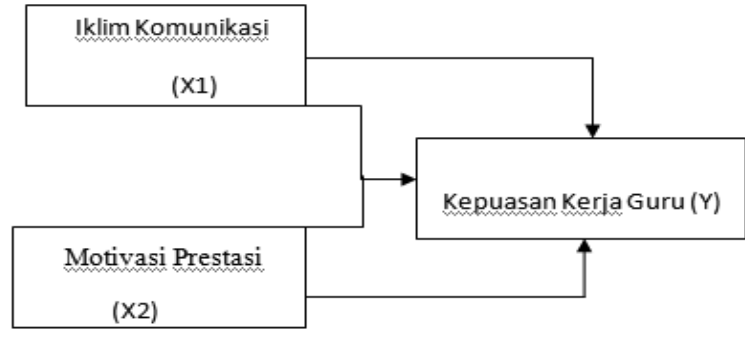

Gambar 2

Kerangka pemikiran kontribusi iklim komunikasi dan motivasi berprestasi terhadap kepuasan kerja guru

Ada beberapa hasil penelitian yang terkait dengan variabel-variabel penelitian ini :

1. Zulhasni Hasan (2004). Kepuasan Kerja Ditinjau dari Kompensasi dan Iklim Komunikasi pada SMK Teknologi Muhammadiyah Bukittinggi.Hasil analisis mengungkapkan kompensasi memberikan sumbangan efektif yang berarti sebesar 
$18,5 \%$ terhadap kepuasan kerja, iklim komunikasi memberikan sumbangan efektif positif yang berarti sebesar 17,3\% terhadap prestasi kerja, sedangkan secara bersama-sama memberikan sumbangan efektif sebesar 32,4\% terhadap kepuasan kerja.

2. Yuyuk Liana (2012) Jurnal tentang Iklim Organisasi dan Motivasi Berprestasi terhadap Kepuasanan Kerja dan Kinerja Guru. Dari hasil analisis diperoleh iklim organisasi berpengaruh signifikan terhadap kepuasan kerja sebesar 0,42, motivasi berprestasi berpengaruh signifikan terhadap kepuasan kerja sebesar 0,42, motivasi berprestasi terhadap kinerja karyawan dengan nilai signifikan 0,40 dan iklim organisasi terhadap kinerja karyawan dengan nilai 0,45 dan antara kepuasan kerja terhadap kinerja karyawan dengan nilai signifikan 0,22 . Hal ini menunjukkan bahwa semua jalur adalah signifikan.

\section{PEMBAHASAN}

Berdasarkan hasil penelitian tingkat kepuasan kerja guru MTsN Langsat Kadap termasuk kategori baik (82\%), iklim komunikas guru MTsN Langsat Kadap termasuk kategori baik $(82,00 \%)$ dan tingkat motivasi berprestasi guru MTsN Langsat Kadap termasuk kategori baik (89\%).

Untuk pengujian persyaratan analisis data pengujian hipotesis menggunakan teknik korelasi dan regresi. Dari persyaratan dinyatakan bahwa dapat dipenuhi yaitu: data berasal dari populasi yang berdistribusi normal
, kelompok populasi mempunyai varians yang homogen dengan menggunakan uji Levene Statistic dan independen antar variabel bebas dengan uji multikolinieritas dengan SPSS dan uji linieritas dengan persamaan $Y=84,025$ $+0,320 X_{1}$ untuk persamaan regresi iklim komunikasi terhadap kepuasan kerja guru dan $\mathrm{Y}=31,137+0,678 \mathrm{X}_{2}$ untuk persamaan regresi linear motivasi berprestasi terhadap kepuasan kerja guru.

Hasil penelitian menunjukkkan bahwa koefisien korelasi $\mathrm{rx}_{1} \mathrm{y}=0,654$ dengan $\rho=$ $0,001<\alpha=0,05$. Ini berarti terdapat hubungan yang signifikan antara iklim komunikasi dan kepuasan kerja guru di MTsN Langsat Kadap Rao Pasaman. . Berdasarkan hasil analisis bahwa iklim komunikasi berkontribusi terhadap kepuasan kerja guru telah teruji secara empiris dan dapat diterima pada taraf 95\%. Besarnya kontribusi iklim komunikasi (X1) terhadap kepuasan kerja guru $(\mathrm{Y})$ adalah sebesar

Hasil penelitian menunjukkkan bahwa koefisien korelasi $\mathrm{rx}_{2} \mathrm{y}=0,776$ dengan $\rho=$ $0,000<\alpha=0,05$. Ini berarti terdapat hubungan yang signifikan antara motivasi berprestasi dan kepuasan kerja guru di MTsN Langsat. Berdasarkan hasil analisis bahwa motivasi berprestasi berkontribusi terhadap kepuasan kerja guru telah teruji secara empiris dan dapat diterima pada taraf $95 \%$ dan telah diuji secara empiris. Besaran kontribusi motivasi berprestasi $\left(\mathrm{X}_{2}\right)$ terhadap kepuasan kerja guru $(\mathrm{Y})$ adalah sebesar $60,3 \%$

Untuk iklim komunikasi dan motifasi berprestasi secara bersama-sama berkontribusi terhadap kepuasan kerja guru MTsN Langsat Kadap Rao Pasaman dapat diterima pada 
taraf kepercayaan 95\% dengan kontribusi sebesar $69,4 \%$, sedangkan sisanya ditentukan oleh faktor lain yang tidak termasuk dalam penelitian ini .

Iklim komunikasi di lingkungan sekolah dapat memberikan manfaat kepada seluruh warga di sekolah, dengan memberikan kesempatan kepada guru secara bergantian menyampaikan dan menerima pesan, berdiskusi, pertemuan berskala untuk evaluasi. Iklim komunikasi yang kondusif sangat dibutuhkan dilingkungan sekolah.

Selain itu untuk memberikan kesempatan kepada guru dan karyawan bertanya, memberikan usul atau saran, maka kepala sekolah dapat mengetahui sejauh mana daya tangkap guru dan karyawan atas pesan yang disampaikan. Usul dan saran yang disampaikan untuk pengembangan sekolah akan semakin memperkaya pemikiranpemikiran baru bagi kepala sekolah

Motivasi berprestasi guru MTsN Langsat Kadap yang dikemukakan diatas dapat menjadi perhatian oleh kepala sekolah. Jika kemauan kerja guru untuk berprestasi sudah muncul, maka harus difasilitasi oleh sekolah segala kebutuhannya dan menciptakan lingkungan yang baik untuk mereka.

Guru yang memiliki motivasi berprestasi tinggi akan berusaha mencoba setiap tugas yang diberikan meskipun sulit untuk dikerjakan. Sebaliknya yang motivasi rendah, akan enggan melakukan tugas yang diberkan apabila ia tahu bahwa dirinya tidak mampu melakukannya, tanpa ada usaha. Bagi guru yang motivasinya tinggi ada dorongan ingin tahunya lebih besar terhadap sesuatu.
Dari teori yang telah dikemukakan dapat dijelaskan ciri-ciri guru yang memiliki motivasi berprestasi yang menjadi perhatian kepala sekolah sehingga tercipta kepuasan kerja guru, diantaranya : 1). Seorang guru mempunyai keinginan untuk bersaing secara sehat dengan dirinya sendiri dengan orang lain. 2) Mempunyai keinginan bekerja dengan baik tanpa menghiraukan pekerjaan orang lain.3) Memiliki tanggung jawab pribadi dan tidak melempar kesalahan kepada orang lain. 4) Mampu membuat terobosan dalam berpikir dengan memberikan ide-ide yang mendukung pengembangan sekolah.

Hasil di atas dapat disimpulkan bahwa kekuatan motivasi berprestasi guru yang tinggi dan peningkatan iklim komunikasi yang baik merupakann dua aspek manajemen sekolah yang sangat urgen untuk peningkatan kepuasan kerja guru. Dengan kata lain semakin kondusif iklim komunikasi dan semakin tinggi kekuatan motivasi berprestasi, maka semakin besar peluang untuk mencapai kepuasan kerja guru, yang kemudian menjadi modal dasar untuk pengembangan guru yang professional.

\section{PENUTUP}

\section{Kesimpulan}

Berdasarkan hasil penelitian dan pembahasan yang telah dikemukakan diatas dapat disimpulkan sebagai berikut:

a. Iklim komunikasi berpengaruh signifikan terhadap kepuasan kerja guru-guru sebesar $42,8 \%$, artinya jika iklim komunikasi baik maka kepuasan kerja akan menjadi 
baik begitu juga sebaliknya. Daya serap responden terhadap variable iklim komunikasi $\left(\mathrm{X}_{1}\right)$ di MTsN Langsat Kadap Rao Pasaman sebesar 82\%. Hal ini berarti daya serap terhadap iklim komunikasi termasuk kategori baik.

b. Motivasi berprestasi berpengaruh signifikan terhadap kepuasan kerja guruguru sebesar $60,3 \%$, artinya jika motivasi berprestasi baik maka kepuasan kerja akan menjadi baik begitu juga sebaliknya. Daya serap responden terhadap variabel motivasi berprestasi $\left(\mathrm{X}_{2}\right)$ di MTsN Langsat Kadap Rao Pasaman sebesar 89\%. Hal ini berarti daya serap terhadap motivasi berprestasi termasuk kategori baik.

c. Iklim komunikasi dan motivasi berprestasi secara bersama-sama berpengaruh signifikan terhadap kepuasan kerja guru-guru sebesar 69,4\%, artinya jika iklim komunikasi dan motivasi berprestasi baik maka kepuasan kerja akan menjadi baik begitu juga sebaliknya. Daya serap responden terhadap variabel iklim komunikasi dan motivasi berprestasi di MTsN Langsat Kadap Rao Pasaman sebesar 89\%. Hal ini berarti daya serap terhadap iklim komunikasi termasuk kategori baik.

\section{Implikasi}

Hasil penelitian ini menunjukkan bahwa iklim komunikasi memberikan konstribusi yang signifikan baik secara sendiri-sendiri maupun secara bersama-sama terhadap kepuasan kerja guru MTsN Langsat Kadap Rao Pasaman. Hal ini mengisyaratkan bahwa untuk meningkatkan kepuasan kerja guru dapat dilakukan dengan menciptakan iklim komunikasi yang kondusif dan meningkatkan motivasi berprestasi.

Untuk menciptakan iklim komunikasi yang lebih kondusif dalam rangka meningkatkan kepuasan kerja guru dapat dilakukan berbagai upaya antara lain komunikasi antara kepala sekolah dan guru, menyediakan informasi yang cukup jelas dan tepat kepada guru, mengikutsertakan guru dalam membuat keputusan sehingga guru merasa dihargai dan tidak merasa dikuasai, serta memberikan dorongan, bantuan dan penghargaan kepada guru yang berprestasi.

Upaya untuk meningkatkan motivasi berprestasi dalam rangka meningkatkan kepuasan kerja guru dapat diusahakan dengan menciptakan kondisi dimana guru merasa tertantang untuk lebih bertanggungjawab. Agar guru merasa tertantang dapat dilakukan dengan berbagai cara seperti memberikan tanggung jawab penuh kepada guru dalam membimbing siswa dan memberikan nilai kepada siswa serta memberikan umpan balik kepada guru-guru atas hasil yang telah dicapai.

\section{KEPUSTAKAAN ACUAN}

Agus Sunyoto, Manajeman Sumber Daya Manusia, Jakarta: IPWI, 1995

Ashar Sunyoto Munandar, Psikologi Industri dan Organisasi, Jakarta: UI Press, 2008

Asnawir, Pengaruh Pelaksanaan Sepervisi Oleh Kepala Sekolah dan Iklim Sekolah Terhadap Motivasi Kerja Guru MAN Sumbar, Disertasi, Jakarta: FSPP, 1986

Davis, Human Behaviorat work: Organizational Behavior. Tokyo: Mc Graw-Hill.Inc 1989 
Golhaber, Gerald dkk, Organizational McCielland dalam Stephen P. Robbin Communication, WCB Publisher: Timotty A. Jugle, Prilaku Organisasi, Dubuque. Iowa, Fifth Edition 1992 Edisi 12(Terjemahan oleh Diana Angelica,

Hasibuan, Melayu. S.P, Managemen Sumber Jakarta: Salemba Empat 2008.

Daya Manusia, Jakarta: Bumi Aksara, 2001. M. As’ad, Psikologi Industri, Yogyakarta:

Herzberg, The Motivation to Work, New York: 1969 Liberty, 2004.

Veithzal Rivai dan Arviyan Arifin, Islamic

Kamus Besar Bahasa Indonesia, Edisis Ketiga, Jakarta: Balai Pustaka,2001.

Mangku Negara, Evaluasi Kinerja, Bandung: Leadership, Membangun Super Leadership Melalui Kecerdasan spiritual, Jakarta: Bumi Aksara, 2009.

Refika Aditama, 2005. 